\title{
Consumption and Teleoaffective Formations: Consumer Culture and Commercial Communications
}

DOI:

$10.1177 / 1469540517729008$

\section{Document Version}

Accepted author manuscript

Link to publication record in Manchester Research Explorer

\section{Citation for published version (APA):}

Welch, D. (2017). Consumption and Teleoaffective Formations: Consumer Culture and Commercial

Communications. Journal of Consumer Culture. https://doi.org/10.1177/1469540517729008

\section{Published in:}

Journal of Consumer Culture

\section{Citing this paper}

Please note that where the full-text provided on Manchester Research Explorer is the Author Accepted Manuscript or Proof version this may differ from the final Published version. If citing, it is advised that you check and use the publisher's definitive version.

\section{General rights}

Copyright and moral rights for the publications made accessible in the Research Explorer are retained by the authors and/or other copyright owners and it is a condition of accessing publications that users recognise and abide by the legal requirements associated with these rights.

\section{Takedown policy}

If you believe that this document breaches copyright please refer to the University of Manchester's Takedown Procedures [http://man.ac.uk/04Y6Bo] or contact uml.scholarlycommunications@manchester.ac.uk providing relevant details, so we can investigate your claim.

\section{OPEN ACCESS}




\section{Consumption and Teleoaffective Formations: Consumer Culture and Commercial Communications}

\section{Abstract}

The paper considers the potential of a novel practice theoretical concept-teleoaffective formation-for the study of consumption. The concept builds upon Schatzki's social ontology of practice. Teleoaffective formations are configurations across multiple practices, that enjoin those practices to common ends, ordering their affective engagements and offering general understandings through which participants make sense of the projects they pursue. The paper argues that the approach affords consideration of large-scale configurations of practice and discourse and therefore enables re-engagement, from a practice theory perspective, with an earlier generation of concerns with consumer culture-including issues of cultural intermediation, consumption norms and the motivational structures of consumption. The distinctive features of the approach are illustrated through three successive teleoaffective formations that link the field of commercial communications (advertising, marketing, public relations, etcetera) with consumer culture. The first-'consumer sovereignty' - originates in the 1920s and ' 30 s and finds its fullest expression in the mid twentieth century. The second-'emancipatory consumerism'-emerged in the late 1960s and came to characterise late twentieth century consumer culture. These are briefly sketched. The third, which I propose to call 'promotional sustainable consumption', is a nascent formation of discourse and practice relating brands, sustainability and consumption. This formation is explored in more depth. The periodisation should not be understood in terms of epochal shifts but as an ongoing, recombinatory process. The three formations represent re-configurations between heterogeneous elements, inter alia: general understandings, teleological orientations, and affective engagements. Each successive formation informs novel understandings of the consumer and provides cultural resources for transformations in consumption norms. Each also provides resources for capitalist legitimation. The article concludes with a brief discussion of some theoretical and methodological implications.

\section{Introduction}

The utility of a practice theoretical approach to consumption is now well established (Halkier et al., 2011; Warde, 2014; Warde et al., 2017; Welch and Warde, 2015). However, advocates of practice theory have acknowledged that a key extant challenge is the development of concepts adequate to the mapping and explanation of large-scale social phenomena (Schatzki, 2016; Nicolini, 2017). In the field of consumption, one such kind of large-scale phenomena are the cultural formations underpinning what an earlier wave of consumption scholarship knew as 'consumer culture' and 'consumerism'. 
Practice theory presented itself as a corrective and an alternative to 'the cultural turn', with its emphasis on 'webs of cultural meanings which constitute symbolic resources for individual choice' (Warde, 2014: 273), and as a way to approach the inconspicuous, routine, habitual, and non-communicative aspects of consumption that the model of consumptionas-culture had ignored. At the same time, theories of practice accommodate two understandings of consumption that are often counter-posed: utilitarian and mundane consumption in the pursuit of everyday tasks on the one hand and, on the other, culturally expressive, symbolic and communicative consumption. For example, Alan Warde's wellknown practice theoretical definition of consumption holds it to be 'a process whereby agents engage in appropriation and appreciation, whether for utilitarian, expressive or contemplative purposes' (2005: 137). Furthermore, social practices are always necessarily cultural practices due to the implicit schemes of knowledge or presuppositions upon which they depend (Reckwitz, 2017a; Rouse, 2007). This said, and excepting those pursuing Bourdieusian analyses, current practice theoretical consumption scholarship has tended to eschew cultural concerns formerly central to sociological engagements with consumption. We could characterise these engagements as: firstly, concern with understanding the cultural expression of a society in which everyday life is dominated by the consumption of commodities provided by the market (or consumerism); and, secondly, how the material culture of mass consumption informs individuals' cognitive, affective and normative engagements with the world (or consumer culture).

There are at least three ways in which practice theoretical approaches have militated away from such concerns. Firstly, there is the already noted corrective focus towards the mundane and ordinary forms of consumption. Secondly, there is the sense in which practice theory has continued the positioning of consumption scholarship against Frankfurt School style critique of commodification, mass culture and 'the culture industry' as well as other forms of twentieth century critique of consumption (e.g. Veblen, Galbraith). Practice theory perhaps even intensified this reaction through its reconceptualization of consumption. ${ }^{\text {is }}$ Graeber has noted, it has become 'a regular instrument of academic socialization' (2011, p. $490)$ to repudiate such negative, 'economistic', non-empirical (and we might add, popular) critical understandings of consumption. Thirdly, I contend, is the focus on practices as the primary unit of analysis (e.g. Halkier et al., 2011; see also Warde, 2013, 2014). Undoubtedly, this move has been extremely generative, but it is, pace the assumptions of many using practice theory, by no means a necessity (see Schatzki, 2016, 2017). The focus on practiceas-unit-of-analysis tends to militate away from the use of concepts that capture the kind of large-scale configurations of discourse and practice that enable engagement with this earlier generation of concerns with consumer culture. Practice theories are particularly sensitive to the issue of reification and this perhaps accounts for their advocates' reticence to develop configurational concepts. This said, it would be highly misleading to characterise scholarship in practice theory as unconcerned with how practices connect with another. Schatzki (2016), for example, offers an abstract notion of "constellations" as, "at bottom nothing but larger 
bundles, larger linkages of practices and arrangements", the existence of which is marked by "concentrations of relations" (p.9). Notable work in this area has elaborated "complexes of practice" that address the "changing material-spatial organisation" of practices (Blue and Spurling, 2017). Furthermore, a number of ontologically compatible concepts of such assemblages of practice and discourse are already common conceptual currency, such as Foucault's 'dispositif', Boltanski and Thevenot's (2005) 'orders of worth', or Hajer's (1995) 'discourse coalitions' (Welch and Warde, 2017). The purpose of such concepts is to render visible phenomena, contexts and relationships previously invisible.

This paper introduces a novel configurational concept-teleoaffective formation. The paper aims to demonstrate that teleoaffective formation enables analytical work in the study of consumption not afforded by the current tendency to focus on practices as the primary unit of analysis, or by existing configurational concepts. Teleoaffective formation is not offered as a critique of existing concepts such as those noted above (or others that could be invoked), but as a conceptual development from Schatzki's social ontology that addresses issues with its sociological operationalisation.

The paper, furthermore, seeks to contribute to a re-engagement with foundational issues in the sociology of consumption: namely, the relationship between consumption and provision, production and capital, and the role of commercial communications (advertising, marketing etcetera) in shaping consumer culture; issues largely marginalised by the current foci of the 'practice turn' (Warde, 2015; Welch and Warde, 2015).

The paper proceeds thus. The following section discusses Schatzki's (2002) notion of teleoaffectivity and its pertinence to the study of consumption and introduces the concept of teleoaffective formation. The following two sections illustrate the concept's use through the analysis of three configurations linking commercial communications and consumer culture in terms of teleoaffective formations. Each represents a reconfiguration of links between practices of cultural production and intermediation on the one hand and consumption on the other. The first and second of these are historical. Both dominated their own widely characterised periods in consumer culture. The first configuration, which I call consumer sovereignty, originates in the 1920s and '30s and finds its fullest expression in the 'scientific' advertising and marketing of the mid twentieth century (Fox, 1984; Marchand, 1985; Schwarzkopf, 2011a, 2011b; Tedlow 1979; Laird, 2001). The second, which I call emancipatory consumerism, finds its full expression following the 'creative revolution' in advertising in the 1960s and the rise of 'motivational research' (Frank, 1997; Lears, 1995; Nixon, 2015; Sivulka, 2011; Schwarzkopf, 2015; Schwarzkopf and Gries, 2010; Warlaumont, 2001). These are briefly sketched. Addressing successive teleoaffective formations demonstrates how such configurations change over time. This periodisation should not be understood in terms of epochal shifts but as an ongoing, recombinatory process, involving novel configurations between heterogeneous elements: general understandings; ends and orientations; affective engagements; consumption norms; subject positions; professional 
techniques; and organisational arrangements. The third configuration, by contrast, is contemporary, nascent, and far from hegemonic. It is a specific formation of discourse and practice concerning the relationship between brands, consumption and sustainability, that I call promotional sustainable consumption. This formation is addressed in more detail in order to demonstrate the use of the concept of teleoaffective formation for understanding contemporary cultural configurations and their potential trajectories. Each successive formation informs novel understandings of the consumer and provides both cultural resources for transformations in consumption norms (Pellandini-Simányi, 2014a, 2014b) and resources for capitalist legitimation. The article concludes with a brief discussion of some theoretical and methodological implications.

The paper draws on secondary sources on the history of consumption and of advertising, marketing and public relations. In addition, the section on promotional sustainable consumption draws upon extensive documentary research on corporate sustainability (practitioner literature, specialist media, corporate communications etcetera) and refers to some primary research, including participant observation with a communications agency and interviews with key informants in the field (see Welch, 2012).

\section{Teleoaffective formations}

Theodore Schatzki's work (e.g. 2002) has served as a central resource for practice theoretical accounts of consumption (e.g. Warde, 2005). My starting point is Schatzki's (2002) concept of 'teleoaffectivity' - which combines the sense of orientation to particular goals and ends (teleology) with the emotions and motivational engagements (affect) enjoined by such orientations. In Schatzki's (2002) schema practices possess their own specific 'teleoaffective structure': a 'range of normativized and hierarchically ordered ends, projects and tasks, to varying degrees allied with normativized emotions' (2002, p. 80), which link the 'doings and sayings' that compose the practice.

The affective dimension offers particular affordances to the sociology of consumption (Illouz, 2009), drawing attention to issues of motivational engagement, and the fundamental role played by emotion in consumption norms (Weenink and Spaargaren, 2016). I can only touch upon the affective dimension in what follows, however the nascent field of practice theoretical approaches to emotion offers fertile possibilities for further development (see Scheer, 2012; Reckwitz, 2017a; Wetherell, 2014; Weenink and Spaargaren, 2016).

The teleological dimension draws our attention to the ends and objects that motivate action and the larger social and cultural projects that practices subtend. However, teleoaffective structures in Schatzki's account are the property of individual practices and 'not equivalent to collectively willed ends and projects' (Schatzki, 2002: 81). The concept is therefore unsuited to capture cultural configurations that cross multiple practices. Schatzki tentatively introduces a further concept - 'teleoaffective regime' (2002: 28)-more suitable to such conceptual work. 
Teleoaffective regimes, by contrast, are articulations of teleology and affectivity that reign across sets of multiple practices (Schatzki, 2015, personal communication) and represent common ordering in the teleoaffective structures of those practices. It is thus a configurational concept that expresses organisation beyond the practices that subtend it (Welch and Warde, 2017). Schatzki (2002: 28) offers examples of teleoaffective regimes among the nineteenth century religious sect the Shakers: faith in salvation through the Shaker order as the Kingdom of God on earth; governing hierarchies through which Shaker life was administered; and a commitment to communal property and living. The first of these perhaps best demonstrates a central difficulty with Schatzki's concept of teleoaffective regime: that it is difficult to conceptually distinguish it from his category of 'general understanding'. For Schatzki (2002: 86), general understandings are a component of individual practices. While they are the property of individual practices, they are common to many practices and condition the manner in which practices are carried out, as well as being expressed in their performance (ibid.). Therefore the relationship between the Shaker's general understanding of the Kingdom of God and the associated teleoaffective regime is left obscure (Welch and Warde, 2017).

The concept of teleoaffective formation seeks to resolve these difficulties. Whilst Schatzki's term is adequate to his case, teleoaffective regime suggests a manner or method of rule or government, uncharacteristic of the range of the more or less coherent teleoaffective formations that pervade the contemporary world. Formation is unencumbered by presuppositions of specific empirical organisation, encompassing wide-ranging phenomena. As such the concept potentially subsumes configurational concepts intended to capture specific kinds of practice-discourse assemblage. Examples of such, noted earlier, include 'orders of worth' (Boltanski and Thevenot, 2006) which addresses public, normative justification and contention, and 'discourse coalition' (Hajer, 1995), which concerns the possibility of local hegemonies. The list of cogent examples is of course longer. For example, Lakoff and Collier (2004: 420) address "configurations of ethical reflection and practice" formed in relation to technology and biopolitics; Jasanoff and Kim (2013) offer "sociotechnical imaginaries", or collectively imagined forms of desirable futures attainable through science and technology carried in practices and representations. Such concepts address specific kinds of configurational order. Teleoaffective formation, by contrast, is offered as a general concept.

As such, the concept of teleoaffective formation is close to the more general Foucauldian notion of 'dispositif'. Reckwitz (2017b) has offered a recent contribution, which, in addressing the affective and motivational aspect of dispositif that Foucault omitted, comes closer still to my own understanding. However, dispositif fundamentally presupposes a singular 'configurational principle that determines how heterogeneous elements...are taken up and recombined' (Collier, 2009:89). Space does not allow a discussion of the plausibility of a structuring, configurational principle emanating from a single general understanding. Teleoaffective formations, by contrast, are characterised by a nexus of general understandings rather than a singular configurational principle. While dispositif is taken to operate at a societal level, arranging segments of social fields into a novel order (Reckwitz, 2017b), teleoaffective formations are conceived as operating at multiple scales. 
They may be coextensive to sociocultural groups, or condition complexes of practice, professions, cultural domains or other slices of praxis (Welch and Warde, 2017). They are more or less densely patterned across sets of practices and social space, enjoin practices to common ends and orchestrate a common normative ordering of orientations and affective engagements of those practices.

Furthermore, and departing from Schatzki (2002), teleoaffective formations are conditioned by a relational nexus of general understandings. Schatzki's first Shaker example- faith in salvation through the Shaker's lived order as the Kingdom of God on earth-also illustrates an important characteristic of teleoaffective formations in my terms: that they express the specification of culturally diffuse general understandings. In the case of the Shakers, the culturally widespread notion of the Kingdom of God was specified as a general understanding in the context of their belief and practice: the Kingdom of God understood as immanent and incarnated in the Shaker order.

A central general understanding in the teleoaffective formations with which this paper is concerned is 'the consumer'. 'The consumer' is a general understanding common to the practices of producers, cultural intermediaries and individuals engaging in consumption. Different teleoaffective formations specify this widespread cultural category as, for example, the "sovereign consumer" or the "citizen-consumer". This specified general understanding of the consumer conditions the practices that carry it and may be explicitly expressed in their performance: individuals may forgo certain products on ethical grounds; brand managers may adapt their marketing strategies to evince 'consumer co-creation' (Zwick et al., 2008) and so forth.

General understandings sit across the boundary between the discursive and the nondiscursive. They may embody tacit or affective aspects (Welch and Warde, 2017). They may issue from discursive formations which exhibit their own principles of organisation distinct from the organisation of the practices they intersect, but which nevertheless carry those general understandings (see Schatzki, 2017). For example, the teleoaffective formation of promotional sustainable consumption discussed below sits at the intersection of several more or less coherent discourses: environmentalism, ethical consumption, brand management, and corporate social responsibility. These discourses are more or less integrated into the practices that embody the teleoaffective formation, such as practices of brand management, of employee engagement within firms, and consumption practices. This character of the formation-as operating at the intersection of multiple discoursesdemonstrates the analytic advantage of approaching the cultural phenomenon as a teleoaffective formation rather than as a discourse in itself.

Teleoaffective formations should therefore be understood as carrying a nexus of general understandings that are specified and conditioned in relation to one another. These nexuses may include both particularised versions of widespread cultural understandings and novel understandings 'general' only to more restricted slices of praxis (professions, subcultures, 
cultural fields, etcetera). It is through these general understandings that focal practices make sense to their participants as part of wider projects under the aegis of the teleoaffective formation.

We are now able to offer a definition of teleoaffective formation: as a configuration across multiple practices, conditioned by a relational nexus of general understandings, that enjoins those practices to common ends and normatively orders the orientations and affective engagements of those practices. At the more integrated we may say teleoaffective formations instantiate an axiology or cosmology which subtends practices and the comportment of its Träger. ${ }^{\text {iii }}$

In the following two sections I discuss a particular kind of teleoaffective formation: large scale configurations of discourse and practice which span and link the practices of cultural production and intermediation in the field of commercial communications (advertising, marketing, public relations etcetera) on the one hand and practices in which consumption is a moment on the other (Warde, 2005). Clearly there is no novelty in claiming the commercial communications professions as important agents in mediating social transformations and the shaping of consumer culture. Rather, the analysis of teleoaffective formations articulates this process in practice theoretical terms, helping to move us beyond an idealist model of the transmission of internalised cultural representations and offering novel insights into processes of cultural intermediation (see Welch and Warde, 2017).

\section{Historical teleoaffective formations in commercial communications and consumer culture}

\section{Consumer sovereignty}

The first historical example emerged in the 1920s and 1930s with the founders of modern commercial communications, such as Edward L. Bernays, often cited as the founder of Public Relations. Bernays advocated a professional ethic of communication requiring the practitioner to represent the public to their client, as well as the client to the public - the socalled 'two way street' (Tedlow, 1979). The anti-democratic aspect of the manipulation of public opinion that Bernays advocated was to be mitigated by binding it to work in the public interest (Tedlow, 1979; Mayhew, 1997). This ethical relation, or representational ideal, translated into mid-century 'scientific' advertising and marketing as the practitioner representing the consumer. US advertising agency J. Walter Thompson exemplified this era, as home to both Stanley Resor, who pioneered the use of demographic data, and John B. Watson, the founder of the American school of behaviourism (Fox, 1984; Kreshel, 1990; Marchand, 1985; Lears, 1995; Laird, 2001).

If the consumer served the public interest by serving the economy of mass consumption (Cohen, 2003), the practitioner was the consumer's advocate, serving the public good by mediating the interests of producers and consumers. The general understanding of consumer sovereignty connected the notion of the consumer with the tenets of democracy; 
drawing more than an analogy between the aggregate consumer choices that move the economy and the aggregate choices realised in democracy, a 'symbolic equation between mass consumers and a democratic electorate' (Schwarzkopf, 2011b: 12; see also Fellner and Spash, 2015).

The development of market research methods in the 1930s and 1940s, such as consumer juries and panel surveys, provided sophisticated techniques for the measurement of consumer preferences, bringing to the fore the notion of the sovereign consumer's choice as a 'vote' in the marketplace conceived as a 'democracy of goods' (Schwarzkopf, 2011b; Tadajewski, 2006). As Schwarzkopf notes, '[b]y that virtue, advertising professionals and consumer researchers were now able to claim a share in the defence of democracy' (Schwarzkopf, 2011b: 13), the more so in the context of the Cold War. Furthermore, from the Depression onwards commercial communications presented its mission as undergirded by an ethical project of creating consumer demand and restoring faith in business (Tedlow, 1979). 'Selling the American way of life to the American people' as Bernays (2013 [1952]) put it, had both an economic function of 'making customers' and a cultural function. Without advertising 'to create new wants and tap old desires', it was warned, 'American industrial progress could not continue' (McMahon 1972: 8). Bernays' (2013 [1952]) 'American way of life' would be sold to the world as a model of modernity: not only ownership of consumer durables and consumption of mass media, but centrally 'the importance of and dignity of the individual' and the 'right to...the good life'.

Grounded upon the quasi-theological figure of the sovereign consumer (Schwarzkopf, 2011a), consumer sovereignty inherited the liberal ideal of the marketplace as a civilising institution, through which subjects not only acquire economic rationality but 'reflect upon themselves as social actors' (Sassatelli, 2001: 97) and on the social obligations of consumption. Consumer choice in this formation was understood less as a celebration of freedom and more as a medium for the refinement of personal value and civic sensibility (Trentmann, 2006). It was in this period that consumption became a political project both bound up with the state and connected to consumerism as a social movement articulating an egalitarian politics of consumption (Hilton, 2009).

We witness here a configuration across multiple practices - stretching from public relations and the demographic surveys and consumer panels of 'scientific advertising', to the organised consumer movement, and to everyday consumption. The nexus of general understandings informing this teleoaffective formation includes: the 'sovereign consumer'; and an understanding of consumer choice within the context of the social obligations of consumption; a model of modernity in which the individual has the right to the 'good life' in the consumer society; the liberal ideal of the marketplace; and an understanding of consumer demand, in which marketing professionals act as advocates and interlocutors of the consumer. These general understandings are carried within tmultiple practices and are embodied in their affective engagements and teleological orientations, including the socio- 
political aspiration of 'prosperity for all', and both the motivational structure of consumption and of professional practice.

\section{Emancipatory consumerism}

'[T]he limitations of the Taylorist style of advertising had become apparent to most of the industry' by the end of the 1950s, writes Thomas Frank: 'And during the '60s they would be swept away along with the bureaucratic agency structures that had created them in a 'creative revolution' that celebrated the mystical carnivalesque properties of creativity and actually embraced the critique of mass society that the ads of the fifties had done so much to inspire' (1997: 39). Whilst there is little agreement in the history of advertising and marketing over periodisation, the significance of this historical transition is widely recognised (Hollander et al.,2005). This 'creative revolution' saw changes in working practices-such as the pairing of copywriters and art directors, and the relative decline in status of account executives (Nixon, 2015) - and large scale change in industry structure, which were to have ongoing effects across the allied communication professions. Of the 92 largest agencies in the US in 1966, 41 no longer existed by 1979 (Leiss et al., 1990).

The 'creative revolution' illustrates how reconfigurations of teleoaffective formations often arise through the activities of actors problematising existing general understandingscommonly in the context of socio-technical and political economic change-and developing novel understandings and practices in response. It also illustrates how reconfigurations commonly involve the articulation of components from minor traditions or countervailing tendencies with mutations in existing understandings. Such components provide a reservoir for transformation when existing dominant formations destabilise. Thus, while the idea of advertising as the servicing of clients or as primarily a creative activity competed intensely throughout the twentieth century (Schwarzkopf, 2009), the novel configuration underpinned the model of the creative practitioner as part of the 'ethical avant garde' of the new consumer capitalism (Bourdieu, 1984: 356). Similarly, psychoanalytically informed 'motivational research' techniques emerged in the 1930s but were marginalised by the logical empiricism and quantitative methods of 'scientific marketing', as well as, in the US context, McCarthyite hostility (Tadajewski, 2006).

The example of emancipatory consumerism demonstrates how teleoaffective formations commonly depend on the supporting scaffold of wider cultural mores. While influences of avant-garde modernism in advertising artwork can be traced back as far as the 1920s and '30s (Lears, 1995), the modernist aesthetics of the creative revolution resonated with the wider cultural context of late ' 60 s and early '70s in which there was a widespread revalorisation of creativity and authenticity. And whilst Bernays' himself anticipated the consumer as an emancipatory figure and drew on psychoanalytical resources as early as the late 1920s (Museum of Public Relations, 2016), emancipatory consumerism found full expression only in resonance with the bohemian, countercultural values of libidinal emancipation. Ernest Dichter's 'motivational research' then found a more favourable 
cultural and political context, enabling him to articulate the emancipatory zeitgeist with the hedonic possibilities of consumption. Dichter advocated motivational research as a vehicle for the desublimation of repressed desire, and emancipation through consumption. Mass consumption, for Dichter, promised to embody a new 'hedonistic morality' (Arviddson, 2003; Schwarzkopf, 2015; Schwarzkopf and Gries, 2010).

However, while the normative model of the emancipated consumer certainly drew on a modernising frame that challenged traditional ethical, affective and aesthetic norms (Arviddson, 2003), the antinomian impulse was, and is, tempered by 'the cult of self-control' (Sassatelli, 2001: 97). Emancipated consumers are nevertheless '[i]ndividuals who are sovereign of themselves and of their will' and desires, and this self-possession marks the boundary from the pathological (Sassatelli, 2001: 96). And yet they are individuals for whom self-realisation is an unquestioned telos in a manner quite alien to the sovereign consumers of the early twentieth century. There are, then, both continuities and profound transformations between the two formations briefly outlined, and the consumption norms that they inform.

\section{Promotional sustainable consumption}

Whereas the historical examples represented dominant formations in consumer culture, promotional sustainable consumption is nascent. While it is far from hegemonic and it competes with the norms and understandings of the earlier formations it would also be wrong to characterise it as a niche. It is institutionalised in business functions, markets and civil society organisations and its powerful advocates champion it as a model for a new, sustainable, consumer culture and as a legitimation for consumer capitalism.

Its novelty is captured in a widely rehearsed narrative concerning the relation of brands to sustainability that has emerged over the last ten years or so. Originating first in the market niche of sustainability communications, this narrative is now articulated by some of the most senior figures in commercial communications and consumer facing corporations.

For example, its opening trope was delivered by the Director of Corporate Responsibility of a UK blue chip to an audience of the company's brand marketeers and consultants:

'Marketing has made unsustainable lifestyles sexy-it is now the responsibility of marketing

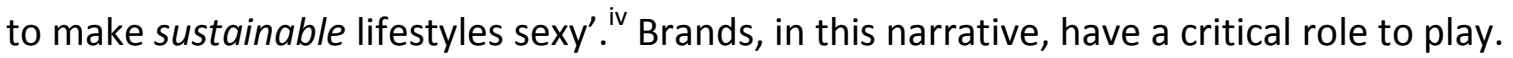
'Really? Surely it is their seductive power that has fuelled our current unsustainable lifestyle?' asked Sally Uren, CEO of charity Forum for the Future on the Guardian Sustainable Business Blog: 'Brands have indeed got us into this mess by encouraging us to buy more and more stuff without any understanding of the wider impact,' continued Uren, 'But brands could help provide some of the solutions' (Uren, 2011: n.p.). That same power of persuasion, the narrative continues, can be harnessed to mobilise the trust that consumers put in brands in order to create a new culture of sustainable consumption. According to the then Chief Executive of Sainsbury's and Chairman of Unilever UK \& Ireland, endorsing Forum 
for the Future's Consumer Futures 2020 report, brands have 'both the power and the responsibility to help people lead better, more sustainable lives. In fact, it's hard to see sustainable consumption becoming mainstream unless brands take the lead' (FftF, 2011: 4). Brands should not wait passively to respond to consumer demand for sustainability, according to the report: 'Savvy brands will make money by accelerating the transition to a more sustainable world' (FftF, 2011: 5).

In this account, brand management has a central role to play in inculcating demand for sustainable consumption. At its most hubristic, we find clarion calls for a capitalist vanguard of the new, sustainable consumer culture. Thus in a report from the Ogilvy \& Mathers agency entitled Mainstream Green: moving sustainability from niche to normal we find a rather breathless account of the extraordinary mood of the corporate elite at the COP-16 climate talks in Cancun, Mexico:

'...the heavy hitters from the private sector were taking matters into their own hands. It is unusual, in these rarified circles, to hear talk of creating a mass movement on everyone's lips...[T]his elite cadre knows that to achieve our goals we must motivate a mass green movement, shifting mainstream consumers to a more sustainable way of living.' (Bennet and Williams, 2011: 10)

While we might dismiss this as hyperbole, if we were to look for a capitalist vanguard the World Economic Forum (WEF) at Davos would be a sensible place to find it. At the 2008 Davos event, chief executives of the WEF Consumer Industry group launched an initiative called 'Driving Sustainable Consumption' 'inspired by the question: What is the business case to start meeting tomorrow's consumer demands today?' (WEF, 2009: 5). Amongst the initiative's corporate backers were five of the largest multinational commercial communications groups: Aegis Media, Edelman, Omnicom Group, Publicis Groupe, and WPP (WEF, 2012: 6). Through a series of annual reports the WEF initiative has rehearsed the narrative outlined above. Its averred goal was to set out a 'normative vision for achieving a more sustainable world by 2030' (WEF, 2009: 6). The WEF reports are unequivocal that 'business as usual' is untenable, calling for a shift from incremental change to radical transformation. The World Business Council for Sustainable Development's (WBCSD) 'Sustainable Consumption Workstream', in which global communications group Havas played an important role, offers the same discourse (e.g. WBCSD, 2010).

To reiterate, a core proposition of this vision is that, far from responding to the aggregate market signals of sovereign consumers, 'businesses must reshape demand' towards sustainable consumption (WEF, 2012: 6). Moreover, 'Brand values...provide signals to consumers about social and behavioral norms' and thus brand management is central to 'decoupling material consumption from consumer value' (WBCSD, 2008: 28).

Thus far corporate efforts to shape sustainable consumption have been rather more prosaic than the aspirations expressed above. However, the project imagined in this discourse does 
find instantiations in practice. It is anchored in reality in four primary sites. It is first and foremost a teleoaffective formation of the professional field of commercial communications itself. From here it is carried into the public sphere, into employee engagement programmes, and into programmes of intervention into consumer practice that brand management informs.

Re-envisaging the role of the consumer as a 'co-creator' of brand value and values is a commonplace of both contemporary academic (e.g. Arvidsson, 2007; Vargo and Lusch, 2004; Zwick, et al. 2008) and brand practitioner discourse. This general understanding of consumers as productive subjects is central to the ambitions of brand management to shape sustainable consumption. As one of my informants put it, there is a 'shared responsibility between consumer and brand' for sustainable consumption. 'The consumer' here is not specified as either the rational, utility-maximising, sovereign consumer whose aggregated activity creates demand, nor as a hedonistic figure emancipated through consumption from the identities and obligations of traditional social milieu. Rather, the consumer is responsibilised (Barnett et al., 2011); understood as exercising consumer choice through the lens of the moral, ethical, or ecological responsibilities expected of them as citizens (Barr and Prillwitz, 2014; Evans, et al.,2017). It is with this citizen-consumer that co-creation of value and meaning with brands takes place. Translating this understanding of the responsible consumer to individuals' lifeworlds is the ambition of advocates of promotional sustainable consumption.

Promotional sustainable consumption thus mediates sustainable consumption by understandings of brand and practices of brand management. As one senior consultant put it, brand is understood 'as the default interface between individuals and institutions'. Promotional sustainable consumption arises within the wider cultural context of the problematisation of consumption. ${ }^{v}$ The widespread diffusion of the discourses of environmentalism and sustainable development from the 1990s onward, and their enactment in the public sphere through mediatised campaigns directed against consumer brands and transnational capitalism in general, have successfully mobilised publics (Bartley et al., 2015). The environmental and ethical consumption movements have actively sought to problematise consumption through such interventions, enlisting 'everyday consumption as a surface of mobilisation for wider, explicitly political aims and agendas', as Barnett et al. put it (2011: 13). These interventions were instrumental in the institutionalisation of corporate social responsibility (CSR) (Bartley et al., 2015). And the discourse of corporate sustainability within consumer-facing firms has largely come to share a general understanding of consumption as a field problematised by environmentalism and ethical consumption, in distinction to earlier understandings of consumption offered by consumer sovereignty and emancipatory consumerism. Promotional sustainable consumption represents commercial communications' own critique of the hedonistic consumer society disembedded from social and environmental obligation, which ironically it claims to have done so much itself to create. 
From the mid-2000s brand management began to deploy sustainability as a set of cultural resources with which to productively engage with this new problematised consumption. However, the promotional logic of branding is reflexive and self-problematizing in character. As Holt (2002: 553) puts it: 'It is not only a solution to corporate communication and identity, but it is also a source of new problems that result precisely from the side effects of success'. Brand has become the locus for communicative struggle over corporate reputation in the public sphere (Knight, 2010).

Thus for brands to achieve value as cultural resources that consumers draw upon they must be perceived as authentic (Holt, 2002). Holt (2002) argues that fierce competition between brands over authenticity raises the bar on claims to authenticity, whilst at the same time brand marketeers are engaged in discursive struggle with activists and sceptical consumers over its meaning. Authenticity has become reframed as the demand that corporations are transparent in their behaviour to employees, consumers, governments and the environment. 'Transparency' has become a key organising logic of contemporary organisations and a general understanding in practices of corporate sustainability. If practices of corporate sustainability are a response to brands' fundamental need for authenticity, promotional sustainable consumption responds to the demand for 'consumer co-creation' specifically (Zwick et al., 2008) - the inveiglement of brands in everyday life. The World Economic Forum's 'Driving Sustainable Consumption' initiative articulates this logic:

'Trust, co-creation and authentic consumer engagement will complement price and logistics as the characteristics of successful businesses in this new world of consumer engagement...building far stronger brands in the process. Sustainability has a strong role to play in the new world of consumer engagement - building social values of sustainability and businesses' trust with consumers around those values...brands have a role to play in changing the world.' (WEF, 2011: 17)

The normative orientations of sustainable consumption are understood as enjoining affective engagements through which individuals' seek to achieve authenticity. Brands seek to position themselves as resources for consumers to draw upon in their quests for authenticity. In return consumers' authentic engagements with brands legitimates them.

A number of theorists of brand have invoked Foucauldian notions of governmentality in the context of consumer-brand co-creation. Arvidsson, for example, characterises brand management as 'a vanguard form of capitalist governance' (2007: 137), synonymous with governmentality. We should be cautious however of confusing the ambitions of programmes of governance with their successful instantiation in processes of subjectification (Barnett et al., 2011), or in conflating the strong claims of brand management with an account of social reality. If for brand practitioners claims to professional jurisdiction lie behind the desire to transform the world into a closer approximation of their model, for the marketing theorists of governmentality the 
motivation to exaggerate consumer co-creation lies in the quest for a paradigmatic example of the appropriation of social practice by capital.

This caveat noted, brand management offers techniques to generate meaning associated with brands in the public sphere (Knight, 2010), and in everyday life. Brand management aims to establish brands as trusted intermediaries of sustainability's normative concerns and in doing so offer themselves as resources for engagement with new consumption norms (Pellandini-Simányi, 2014a, 2014b), for example reducing the environmental impact of one's own consumption or fostering improvements in the conditions of distant others through buying Fairtrade products.

To reiterate, promotional sustainable consumption seeks to mobilise the idea of sustainability, and the consumption norms it informs (Pellandini-Simányi 2014a, 2014b), for projects of consumer-brand 'co-creation' (Zwick et al, 2008), through which brands' appeals to authenticity are made (Holt, 2002). I make no strong claim for the realisation of this ambition in everyday life. As noted, existing corporate engagements with sustainable consumption have been, as yet, more limited than the ambitions of its commercial advocates: the marketing of putatively more sustainable goods and services; didactic campaigns; incentivising consumers; and communication work to realise the environmental benefits of product innovation, such as low temperature washing powder (see Mylan, 20167). However, there is an emerging trend towards corporations' attempts to intervene in consumer practice in the name of sustainable consumption. Walmart and Unilever, for example, have collaborated to encourage water and energy saving through taking shorter showers, seeking to intervene in the everyday practices in which products are used (Edie.net, 2011). Supermarkets have sought to make interventions in household provisioning and cooking practices to promote food waste reduction (Evans et al., 2017). We begin to see here the contours of the teleoaffective formation in the norms, affective engagements and general understandings of consumption.

Where we do find promotional sustainable consumption more strongly instantiated is in programmes of 'employee engagement' within firms. Advising on and designing employee engagement programmes is a major aspect of the work of communications agencies specialising in sustainability-probably more significant than consumer facing communications. The value of 'employee engagement' is widely acknowledged in contemporary business discourse. An exemplary report on 'embedding sustainability' in firms, produced at Ashridge Business School in the UK, and drawing on research that reviewed 176 sustainability reports and interviewed 44 senior practitioners, concludes: 'What differentiated the real pioneers was the intersection of brand, culture and how they are framing sustainability' (Stubbings and Ceasar, 2012: 1). Here, brands are understood as having value and meaning to employees of brand-owning firms, as much as to consumers. Zwick et al. (2008) note that 'the image...of a brave new world [of] co-creation' of value and meaning between consumers and brand 'has diffused quickly through the halls of business 
schools and corporations' (Zwick et al., 2008: 164). The 'embedding' extolled by the Ashridge report is just such a form of co-creation. For many, workplace initiatives are likely to be the most common form of engagement with sustainable consumption. The more advanced employee engagement programmes aim to intervene in the everyday practices of workers' consumption activity outside the workplace. For example, BT Group announced a target of having $20 \%$ of their workforce 'actively involved in carbon reduction initiatives at home and work by 2012' (BT Group, 2012). Brand and sustainability are woven together to positively channel affect in corporate culture. By engaging with employees through everyday consumption, the teleoaffective formation offers new and powerful resources for corporations to motivate employees and for employees to pursue lifestyle and identity projects.

To summarise, promotional sustainable consumption arose within the field of commercial communications and its understandings and orientations have come to have a significant impact on consumer-facing corporations. For commercial practitioners-communications specialists, sustainability professionals and brand managers - the project of promotional sustainable consumption makes sense through a nexus of specified general understandings of brand, the consumer, consumption, authenticity, transparency and sustainability. These general understandings condition professional practice and are diffused more widely through corporate engagements in the public sphere, employee engagement programmes, and corporate programmes of intervention into consumer practice. Through these routes the teleoaffective formation comes to inveigle itself into the practices of everyday life, shaping consumption norms and conditioning the teleoaffective structures of those practices - their orientations, and the emotional and motivational engagements they enjoin.

\section{Conclusion}

This paper aims to make a theoretical contribution to practice theory with pertinence for the study of consumption. It contributes to conceptual development within theories of practice by introducing a configurational concept-teleoaffective formation -that renders visible assemblages of discourse and practice less easily apprehended if we take practices as unit of analysis as our primary orientation. For the study of consumption, the approach offers a distinctive perspective to questions concerning consumer culture, cultural intermediation, consumption norms and the motivational structures and affective engagements of consumption.

The danger of configurational concepts is reification. To avoid reifying teleoaffective formations their identification should be empirically grounded in the practices they subtend. They are never more than a particular kind of nexus of relations between practices. Such a nexus is characterised firstly by mutually conditioning teleoaffective structures and common general understandings, but also by, inter alia, material, economic, and aesthetic relationships implicated by the common orientations such formations establish.. For example, promotional sustainable consumption seeks to recruit everyday life practices, 
through the medium of brands, to capital accumulation. Methodologically this implies tracing relationships across multiple practices and sites. Promotional sustainable consumption, for example, extends via the practices of brand management into corporations, consumption and the public sphere. Its translation to these sites occurs through both mobile general understandings and specific practices (e.g. employee engagement). The approach requires 'zooming in' and 'zooming out' (Nicolini, 2017) from the granularity of individual practices to 'overviews' of larger scale social and cultural formations (Schatzki, 2016). There are useful antecedents in ethnographic approaches that seek to connect multiple sites or the focal research site with non-local contexts and processes, such as commodification (e.g. Marcus, 1998).

In this paper I have focused on the nexuses of general understandings through which focal practices make sense to their participants (whether the work practices of marketing professionals or everyday practices understood through the lens of sustainable consumption). Such nexuses demonstrate configuration across multiple practices. General understandings normatively condition the teleoaffective structures of practices (Welch and Warde, 2017). In the formations discussed in this paper this is reflected in changes in consumption norms. For example, the ideal of authenticity promoted by emancipatory consumerism, drawing on the Romantic cult of the artist, avant-garde modernism, countercultural and psychoanalytical resources, emphasised the liberation of the self from traditional cultural restraints and oppressive social relations and was reflected in novel aesthetics and values of consumption (Frank, 1997; Schwarzkopf, 2015). While authenticity remains a central understanding of promotional sustainable consumption, the previous emancipatory form is overlaid with an novel understanding of authentic self-realisation through the integration into lifestyle of norms of care for the environment and distant others, in which consumption is the crucial medium. This example also demonstrates how reconfiguration consists of novel relations between both new components (e.g. sustainability) and elements of continuity (e.g. authenticity), through which existing understandings may undergo transvaluation.

There are other potential empirical entry points to teleoaffective formations that might be explored. One such suggested by Wetherell (2014: 21) is to focus analysis on what she calls 'affective practices', 'patterned social activities which produce the psychological subject and constitute what is conventionally understood as an emotional scene' and the social, cultural and institutional 'connections between...emotional performances and other ordering and organizing constituents'.

Analysing teleoaffective formations potentially offers resources with which to ground critique of consumption, by engaging with questions concerning the linkages between the orientations of consumption and wider socio-economic configurations. The formations identified here might be thought of as capitalist imaginaries, invested to greater or lesser degree in sites of production, provision, intermediation and consumption. Each has 
provided resources for capitalist legitimation. Furthermore, all three formations arose within a context of crisis and political economic transformation. Just as emancipatory consumerism was the answer in the arena of consumption to the breakdown of the Fordist and Keynesian settlement, promotional sustainable consumption responds to the current crisis of capitalism, and the global sustainability crisis with which it is deeply implicated. While this emerging formation is, as yet, more an imagined future of sustainable consumption than realised ambition, we should take seriously the ambitions of its powerful advocates, such as the World Economic Forum and World Business Council for Sustainable Development.

Lastly, the teleoaffective formations described here-arising from the purposive projects of collective actors - are assemblages of a particular sort. Quite other kinds of projects, such as 'making a home' or 'raising a family', may be understood through the lens of teleoaffective formations. Whether certain projects such as 'romance' or 'parenting' are better understood as integrative practices (Schatzki, 2002) or as teleoaffective formations needs to be determined by empirical analysis. A possibility to be explored is the oscillation of such configurations across social space or historical time between the level of organisation of activity represented by practices and the more diffuse organisation of teleoaffective formations.

Patterns of consumption are significantly linked to such projects. Furthermore, such formations are often the object of interventions in the name of sustainable consumption. Practice theory has provided novel insights into multiple kinds of linkage-material, temporal, social-that configure such formations. However, its current form has proved less generative at addressing their cultural, affective and motivational aspects. The lens of teleoaffective formations potentially opens up novel avenues to pursue such research.

\section{Acknowledgments}

I would like to thank Alan Warde and three anonymous reviewers for helpful comments, as well as Ted Schatzki for his encouragement. Thanks also to David Evans, Dale Southerton, Luke Yates, and Alan again, for numerous discussions that have influenced the development of this work. An earlier version of this paper was presented at the 2014 European Sociological Association Consumption Research Network Conference, University of Porto.

\section{Funding}

The research presented in this article was funded by the Sustainable Consumption Institute, University of Manchester, UK.

\section{References}

Arvidsson, A. (2003) Marketing Modernity. London: Routledge 
Arvidsson, A. (2007) Brands: Meaning and Value in Media Culture. London and New York: Routledge

Barnett, C., Clarke, N., Cloke, P. and Malpass, A. (2011) Globalizing Responsibility: The Political Rationalities of Ethical Consumption. Chichester: Wiley-Blackwell.

Barr, S. and Prillwitz, J. (2014) 'A smarter choice?' Environment and Planning C. 32(1):1-19

Bartley, T., Koos, S., Samel, H., Setrini, G. and Summers, N. (2015) Looking behind the Label. Bloomington: Indiana University Press

Bernays, E.L. (2013 [1952]) Public Relations. Norman: University of Oklahoma Press

Bennett, G. and Williams, F. (2011) Mainstream Green. Ogilvy \& Mathers.

https://assets.ogilvy.com/truffles_email/redpaper_june2010/MainstreamGreen.pdf, accessed 10/06/16

Blue, S. and Spurling, N. (2017) "Qualities of connective tissue in hospital life" in A. Hui, T. Schatzki, and E. Shove (eds.) The nexus of practice. London: Routledge

Bräuchler, B. and J. Postill (eds.) (2010) Theorising Media and Practice. Oxford: Berghahn.

BT (2012) 'Engaging our employees'

www.btplc.com/Responsiblebusiness/Ourpeople/Engagingouremployees/index.htm, accessed 18/08/12

Boltanski, L. and Thévenot, L. (2006) On Justification. Princeton: Princeton University Press Bourdieu, P. (1984) Distinction. Cambridge, MA: Harvard University Press

Cohen, L. (2003) A Consumer's Republic. New York.

Collier, S. J. (2009) 'Topologies of Power' Theory Culture \& Society. 26(6):78-108

Edie.net (2011) 'Unilever and Walmart in joint water saving campaign' www.edie.net/news/4/Unilever-and-Walmart-in-joint-water-saving-campaign/21175/, accessed 27/03/2015

Evans, D., Welch, D. and Swaffield, J. (2017) 'Constructing and mobilizing 'the consumer: Responsibility, consumption and the politics of sustainability' Environment and Planning $A$. Epub ahead of print. DOI:10.1177/0308518X17694030

Fellner, W. J. and Spash, C. L. (2015) 'The role of consumer sovereignty in sustaining the market economy'. In L. Reisch and J. Thøgersen (eds.) Handbook of Research on Sustainable Consumption. Cheltenham: Edward Elgar 
FftF (2011) 'Consumer Futures 2020' Forum for the Future www.forumforthefuture.org/sites/default/files/project/downloads/consumer-futures-2020full-document.pdf, accessed 10/06/16

Frank, T. (1997) The Conquest of Cool. Chicago: University of Chicago Press

Fox, S. (1984) The Mirror Makers. New York: Morrow

Foucault, M. (2001) Fearless Speech. New York: Semiotext

Graeber, D. (2011) “Consumption” Current Anthropology 52(4): 489-511

Hajer, M (1995) The Politics of Environmental Discourse. Oxford: Clarendon.

Halkier, B. (2010) Consumption Challenged. Farnham: Ashgate

Halkier, B., Katz-Gerro, T. and Martens, L. (eds.) (2011) 'Applying Practice Theory to the Study of Consumption' Journal of Consumer Culture 11(1):3-13

Hilton, M. (2009) Prosperity for all. Ithaca, NY: Cornell University Press

Hollander, S., Jones, D., Rassuli, K., and Dix, L. (2005) 'Periodization in marketing history' Journal of Macromarketing 25(1):32-41

Holt, D.B. (2002) 'Why Do Brands Cause Trouble?' Journal of Consumer Research 29:70-90

Illouz, E. (2009) 'Emotions, Imagination and Consumption' Journal of Consumer Culture 9(3): $377-413$

Jasanoff, S. and Kim, S-H. (2013) Dreamscapes of Modernity. Chicago University Press.

Keller, M. and Halkier, B. (2014) 'Positioning consumption' Marketing Theory 14(1) pp.35-51

Knight, G. (2010) 'Activism, Branding and the Promotional Public Sphere' in M. Aronczyk and D. Powers (eds.) Blowing up the Brand. New York: Peter Lang

Kreshel, P. J. (1990) 'John B. Watson at J. Walter Thompson' Journal of Advertising 19(2), 49-59

Lakoff, A. and Collier, S.J. (2004) "Ethics and the anthropology of modern reason" Anthropological Theory 4(4):419-43

Laird, P. W. (2001) Advertising Progress. Baltimore: Johns Hopkins University Press Lears, T. (1995) Fables of Abundance. New York: Basic Books

Leiss, W., Kline, S. and Jhally, S. (1990) Social Communication in Advertising. Routledge: London. 
McMahon, A.M. (1972) 'An American Courtship: Psychologists and Advertising Theory in the Progressive Era' American Studies 13(2):5-18

Marchand, R. (1985) Advertising the American Dream: 1920-1940. Berkeley: University of California Press

Marcus, G.E. (1998) Ethnography through Thick and Thin. Princeton: Princeton University Press

Mayhew, L. (1997) The New Public: Professional Communication and the Means of Social Influence. Cambridge: Cambridge University Press

Museum of Public Relations (2016) http://prvisionaries.com/bernays/bernays_1929.html, accessed 21/07/16

Mylan, J. (2016) 'The Business of "Behaviour Change" Organization \& Environment Epub ahead of print 22 Nov 2016

Nicolini, D. (2017) 'Is small the only beautiful?' In A. Hui, T. Schatzki and E. Shove (eds.) The Nexus of Practice. London: Routledge

Nixon, S. (2015) "Looking westwards and worshipping: The New York 'Creative Revolution' and British advertising, 1956-1980" Journal of Consumer Culture. Epub ahead of print DOI: $10.1177 / 1469540515571388$

Pellandini-Simányi, L. (2014a) Consumption Norms and Everyday Ethics. Palgrave McMillan Pellandini-Simányi , L. (2014b) 'Everyday consumption norms as discourses of the good life in presocialist and socialist Hungary' Journal of Consumer Culture Epub ahead of print 26 May 2014

Reckwitz, A. (2017a) 'Practices and their affects' In Hui A, Schatzki TR and Shove E (eds.) The nexus of practice. London: Routledge

Reckwitz, A. (2017b) The Invention of Creativity. Cambridge: Polity

Rouse, J. (2007) 'Practice theory' Handbook of the philosophy of science. Division I Faculty Publications: WesScholar

Sassatelli, R. (2001) 'Tamed Hedonism' in J. Gronow and A. Warde (eds.) Ordinary Consumption. London: Routledge

Schatzki, T. (2002) The Site of the Social. University Park, PA: Pennsylvania State University Press

Schatzki, T. (2016) 'Keeping Track of Large Phenomena' Geographische Zeitschrift 104(1): 4-24 
Schatzki, T. (2017) 'Sayings, texts and discursive formations' In Hui A, Schatzki TR and Shove E (eds.) The nexus of practice. London: Routledge.

Scheer, M. (2012) 'Are Emotions a Kind of Practice?' History and Theory 51: 193-220

Schwarzkopf, S. (2009) 'What Was Advertising?' Business and Economic History Online 7:127

Schwarzkopf, S. (2011a) 'The Political Theology of Consumer Sovereignty' Theory Culture \& Society 28:106-129

Schwarzkopf, S. (2011b) 'The Consumer as 'Voter,' 'Judge,' and 'Jury' Journal of Macromarketing 1:8-18

Schwarzkopf, S. (2015) 'Mobilizing the depths of the market' Marketing Theory 15(1):39-57

Schwarzkopf, S. and Gries, R. (eds.) (2010) Ernest Dichter and motivation research London: Palgrave

Sivulka, J. (2011). Soap, sex, and cigarettes: A cultural history of American advertising Belmont: Wadsworth

Stubbings, A. and Ceasar, N. (2012) 'Sustainability as usual' Directions February, pp. 1-4. Ashridge Business School

Tadajewski, M. (2006) ‘Remembering motivation research’ Marketing Theory 6:429-466

Tedlow, R. S. (1979) Keeping the Corporate Image: Public Relations and Business, 19001950. Greenwich, CT: JAI Press

Trentmann, F. (2006) 'Knowing Consumers' in F Trentmann (ed.) The Making of the Consumer. Oxford: Berg.

Uren, S. (2011) www.guardian.co.uk/sustainable-business/blog/green-branding-marketingconsumer-behaviour?INTCMP=SRCH, accessed 04/07/14

Vargo, S.L. and Lusch, R.F. (2004) 'Evolving to a New Dominant Logic for Marketing' Journal of Marketing, 68:1-17

Warde, A. (2005) 'Consumption and Theories of Practice' Journal of Consumer Culture 5(2):131-153

Warde, A. (2013) 'What sort of a practice is eating?' in E. Shove and N. Spurling (eds.) Sustainable Practices. London: Routledge.

Warde, A. (2014) 'After taste: Culture, consumption and theories of practice' Journal of Consumer Culture, 14(3):279-303 
Warde, A. (2015) 'The Sociology of Consumption: Its Recent Development' Annual Review of Sociology 41:117-34

Warde, A., Welch, D and Paddock, J. (2017) 'Studying Consumption through the Lens of Practice'. In M. Keller, B. Halkier, T.A. Wilska, M. Truninger (eds.) Routledge Handbook on Consumption London: Routledge

Warlaumont, H. G. (2001) Advertising in the 60s. Westport: Praeger

World Business Council on Sustainable Development (WBCSD) (2008) Sustainable Consumption: Facts and Trends Report. Available at:

www.wbcsd.org/content/search?searchText=\%22Sustainable+Consumption\%22\&searchBut ton $=\&$ page $=2$ (accessed 23 August 2017)

World Business Council on Sustainable Development (WBCSD) (2010) A vision for sustainable consumption. Available at: http://www.wbcsd.org/Clusters/SustainableLifestyles/Resources/A-Vision-for-Sustainable-Consumption (accessed 10/06/16)

Weenink, D. and Spaargaren, G. (2016) 'Emotional Agency Navigates a World of Practices' in Gert Spaargaren, Machiel Lamers and Don Weenink (eds.) Practice Theory and Research. London: Routledge

Welch, D. and Warde, A. (2015) 'Theories of Practice and Sustainable Consumption'. In L. Reisch and J. Thøgersen (eds.) Handbook of Research on Sustainable Consumption. Cheltenham: Edward Elgar

Welch, D and Warde, A. (2017) 'How should we understand 'general understandings'?' In Hui A, Schatzki TR and Shove E (eds.) The nexus of practice. London: Routledge

Welch, D. (2012) Understanding the Commercial Field of Sustainability Communications. Unpublished PhD. Thesis. University of Manchester.

World Economic Forum (WEF) (2009) Sustainability for Tomorrow's Consumer. World Economic Forum, www3.weforum.org/docs/WEF_Cl_SustainabilityForTomorrowsConsumer_Report_2009.pdf accessed 10/06/16

World Economic Forum (WEF) (2011) The Consumption Dilemma: Leverage Points for Accelerating Sustainable Growth. Available at: https://www.weforum.org/reports/consumption-dilemma-leverage-points-acceleratingsustainable-growth (accessed 10 June 2016)

World Economic Forum (WEF) (2012) More with Less. World Economic Forum, www.weforum.org/reports/more-less-scaling-sustainable-consumption-and-resourceefficiency, accessed 10/06/16 
Wetherell, M. (2014) 'Trends in the Turn to Affect' Body \& Society. Epub ahead of publication 21 July 2014

Zwick, D., Bonsu, S.K. and Darmody, A. (2008) 'Putting Consumers to Work' Journal of Consumer Culture 8(1):168-196

Zwick, D. and Cayla, J. (eds.) (2011) Inside Marketing. Oxford: Oxford University Press

\footnotetext{
'If consumption is a moment in almost every practice (Warde, 2005), and we give social practices their due, acknowledging their autotelic orientations and internal goods, it is hard to construe either a telos for consumption itself, or find ground for its critique.

ii Exceptions regarding communications include Halkier (2010) and Keller and Halkier (2014). By further caveat, note the practice-orientated literature addressing marketing (e.g. Zwick and Cayla, 2011) and media (e.g. Bräuchler and Postill, 2010).

iii We might consider Weber's 'this-worldly asceticism' in The Protestant Ethic and the Spirit of Capitalism as a teleoaffective formation. While for many commentators modes of subjectification are central to such formations I have purposefully not foregrounded subjectification here, the better to distinguish the approach from accounts of governmentality (e.g. Arvidsson, 2007).

iv 'Brand Forum' event, central London 23/05/07

v Problematisation is understood here in Foucault's sense, in which 'an unproblematic field of experience or set of practices which were accepted without question...becomes a problem, raises discussion and debate, incites new reactions, and induces a crisis in the previously silent behaviour, habits, practices and institutions' (Foucault, 2001: 74).
} 